\title{
Built Environment or Household Life-Cycle Stages-Which Explains Sustainable Travel More?
}

\section{$\operatorname{AUTHOR}(\mathrm{S}):$}

Sun, Yilin; Waygood, E. Owen D.; Fukui, Kenichiro; Kitamura, Ryuichi

\section{CITATION:}

Sun, Yilin ...[et al]. Built Environment or Household Life-Cycle Stages-Which Explains Sustainable Travel More?. Transportation Research Record: Journal of the Transportation Research Board 2009, 2135: 123-129

ISSUE DATE:

2009-12-01

URL:

http://hdl.handle.net/2433/128872

\section{RIGHT:}

(C) 2009 National Academy of Sciences; This is not the published version. Please cite only the published version.; この論文は出版社版で ありません。引用の際には出版社版をご確認ご利用ください。 
THE BUILT ENVIRONMENT OR HOUSEHOLD LIFECYCLE STAGES: WHICH EXPLAINS SUSTAINABLE TRAVEL MORE? THE CASE OF KYOTO-OSAKAKOBE BUILT AREA

Yilin Sun $^{1}$

yilin@trans.kuciv.kyoto-u.ac.jp

E. Owen D. Waygood ${ }^{1}$

owen@trans.kuciv.kyoto-u.ac.jp

Kenichiro Fukui ${ }^{2}$

fukui-kenichirou51@hankyu-group.jp

Ryuichi Kitamura $^{3}$

rkitamura@trans.kuciv.kyoto-u.ac.jp

$1 \mathrm{PhD}$ Candidate

Department of Urban Management

Kyoto University

C Cluster Katsura Campus

Nishikyo-ku, Kyoto, Japan

P: +81-75-383-3242

F: $+81-75-383-3236$

2 Urban Transportation Planner

Urban Transportation Planning Dept.,

Hankyu Corporation

1-16-1 Shibata Kita-ku Osaka

530-8389 JAPAN

P: +81-6-6373-5031

\section{Professor}

Department of Urban Management

Kyoto University

C Cluster Katsura Campus

Nishikyo-ku, Kyoto, Japan

P: +81-75-383-3238

F: $+81-75-383-3241$

Word Count: $3822+3$ Figures +6 Tables $=5822$ 


\begin{abstract}
Sustainable travel is a goal deserving of research and implementation, but how such a goal can be reached is debated. Fueling this debate are the many different factors involved in individual travel ranging from values and beliefs to the impact of the built environment. The amount of impact that the built environment may have can be clouded by a person's personal preference for a certain lifestyle and different lifecycle stages have different levels of travel. Although low levels of automobile use have been observed in city centers, the question remains as to whether the demographics of the distinct developed areas can explain the differences. This paper investigated the fraction of automobile trips across different developed areas for households of distinct lifecycle stages to determine which explained the differences greater. The results suggest that it is the built environment that has a greater ability to explain the differences in the fraction of automobile trips and that households of the same lifecycle stage retain the same basic number of trips.
\end{abstract}




\section{INTRODUCTION}

Sustainable travel has many aspects to it, but a dominant theme is the reduction of energy required to accomplish trips. In Japan, a study on per passenger energy use for different motorized modes found that passenger cars used nearly twice that of city bus passengers and over six times that of train passengers per kilometer (1). In many countries, a general increase in the share of automobile trips has been documented (2), suggesting a corresponding increase in energy use. However, given a built environment that facilitates all modes, the percentage of trips that are by an automobile may be small despite increases in wealth and automobile ownership, but it has been difficult to distinguish the role of the built environment on travel behavior. Creating more sustainable travel will require changing people's behavior and changing the built environment is just one aspect of that.

Changing people's behavior is a difficult thing. Education to change behavior may work in a situation where the desired behavior already exists and only needs reinforcement. In a situation where the change in behavior is difficult because of factors such as limited choice or psychological barriers such as group behavior, behavior change may require stronger guidance than education such as laws. Group behavior is the tendency for humans to follow the majority's actions and conversely, for the group to seek compliance from individuals. Increasing laws to restrict certain behavior may not be politically feasible if they go against the majority's behavior or social norms. In terms of sustainable travel, education to increase the use of modes other than private automobiles may work if there is the appropriate infrastructure and supporting features such as local stores and safe routes for nonmotorized modes. But in situations where that does not exist, travel behavior change may be more difficult. Changing the built environment is a major step and questions concerning the extent of its effect on travel behavior still exist.

Changing the built environment has been suggested as a method to reduce automobile use (3) and some studies have shown a difference in travel behavior between neighborhoods built prior to 1945 and those built after (4). On the other hand, some authors assert that individual and household circumstances have greater influence over travel behavior than do land use patterns (5). Personal preference may also contribute to differences seen between neighborhoods. If people who prefer to walk or cycle seek out neighborhoods where they feel comfortable doing so, the impact of the built environment may be exaggerated. This is termed "residential self-selection" and is discussed further below. Other research on the same group of people before and after a move suggest that travel behavior may be especially entrenched for private automotive vehicle users $(6,7)$ and that the built environment has low explanatory power.

Residential self-selection is a factor that can affect the differences seen between neighborhood styles. Cao et al. (8) covers this topic well and summarizes that the built environment does have its own distinct influence on travel behavior separate from that of residential self-selection. Although this paper does not specifically address characteristics of neighborhoods such as sidewalk availability (though it should be noted that sidewalks are not prevalent in the study area, typically only existing by major roads) or parking availability, it does distinguish the developed areas according to diurnal population changes, and the relative amount of commercial development and employment available locally. Having locally available employment reduces the distance required to commute, which can facilitate nonmotorized modes of travel more easily.

Certainly personal preference will contribute to travel behavior, but can it explain the extreme differences seen between major centers such as the Kei-Han-Shin area (abbreviation for an area encompassing Kyoto, Osaka, and Kobe) and Los Angeles (9). Without a doubt, culture plays some part in the differences, but then similar differences in travel behavior can increasingly be seen within the Kei-Han-Shin area between different development styles. 
Japan has developed a built environment often centered around a train station and with mixed land-use, two aspects of Transit Oriented Design (TOD). Although it is not free of increased automobility, the choice to do shopping trips locally is still possible and a large percentage (roughly 60\%) is by non-motorized modes (10) in the Kei-Han-Shin area. However, not all areas have developed in this TOD-like method and suburban areas have seen a greater increase in total trip energy consumption than urban areas (9). For that study, the Kei-Han-Shin area was divided into 194 geographical areas and classified as urban, suburban, and unurbanized (10).

One possible explanation for this increasing difference is the household makeup of each area. It could be that older people are remaining in the city, continuing in their "entrenched" behavior, and that young families are establishing themselves in less developed areas. If however, households of the same lifecycle stages were compared across different developed areas, then the impact of the built environment may become evident.

Unfortunately, personal preference may still rear its head here. People may choose to live in a certain area because of lifestyle preferences. Living in an area where easier movement by private vehicle is possible may allow for a greater number of trips or perhaps less time to accomplish tasks. Therefore, it is important to consider the number of trips. If the number of trips were similar within households of the same lifecycle stage across different developed areas, then it could be surmised that they have similar levels of activity.

This paper will examine the concepts discussed above by first explaining how the different built environments were identified for the Kei-Han-Shin area. Then, to look at changes in automobile use across the different built environments, repeated cross-sectional data were used from 1970, 1980, 1990, and 2000 to examine the change in the fraction of automobile trips over time across the different areas. Distinct lifecycle stages for each household were identified and cross-sectional data for the year 2000 were used to investigate if differences between the built environments remained. The same data were then used to determine the average number of household trips, and then averages are compared in order to consider lifestyle differences.

\section{STUDY AREA AND CHARACTERISTICS}

The study was completed in the Kyoto-Osaka-Kobe developed area of western Japan. The population was 18.2 million and the area $9,223 \mathrm{~km}^{2}$, which results in a population density of 1975 people $/ \mathrm{km}^{2}$ (5115 people $/ \mathrm{m}^{2}$ ). The developed area was characterized by mixed land-use in all areas. Although the urban areas are quite developed, suburbanization exists. However, the style of suburbanization is different from typical North American suburban developments in that shops and services may still exist within neighborhoods and train stations are present and are often used by commuters.

The national average of household car ownership in Japan was 1.12, but the study area had an average of 0.97 . It varied from 0.5 in the urban centers to 1.37 in the lower density developments. Private vehicles did not necessarily offer a significant mobility advantage in the urban areas where shops were nearby and roads were narrow with a high number of users, both automotive and non-automotive.

The area has a long history of rail development with urban rail being established in the main cities before 1900 . Although some of the rail lines were previously nationally owed, all rail lines in the area are presently privately operated. Residential areas have traditionally developed around train stations, though this trend has somewhat changed in the past couple of decades.

It should also be emphasized that although zoning does exist in Japan, it is not nearly as strict as seen in North America. Even in the strictest residential zoning from the 1968 City Planning Law, multi-dwelling development, stores, and offices area allowed (11). Prior to 
this law, even less strict zoning applied from the 1919 City Planning Law (for a detailed description of the development of Japanese urbanization, please see Sorenson (11)). As a result, practically all urban areas could be termed mixed land-use. This may lead to lower car-dependency than seen in more strict zoning development.

The data used to determine lifecycle stages came from large-scale household travel surveys which are conducted every 10 years since 1970 . The data used to distinguish different kinds of developed areas is shown later in the paper.

There were two main stages to this analysis. The first examined the study area and used available information to define different developed areas. The second method used socio-demographic information from a repeated cross-sectional travel survey to determine the lifecycle stage of each household. These two stages are described in detail below.

\section{IDENTIFYING DIFFERENT BUILT ENVIRONMENTS}

This section gives details about how the distinct developed areas were determined. The areas' boundaries were determined by political boundaries established by the Japanese government. A considerable amount of information about the residences' characteristics, the densities of both people and shops, along with the employment situation was used to identify the different developed areas. The different divisions of information that were considered, the specific factors, and their sources are shown in Table 1.

Analysis on these factors was done using cluster analysis and five basic developed areas were identified: commercial, mixed commercial-residential, mixed residential, autonomous, and emerging. The resulting divisions are shown in Table 2. The basic definitions of each area are:

1) A highly commercial mixed area is an area with the highest densities of commercial development. These areas have a high day-time population with respect to the night-time population.

2) Mixed commercial areas have a high density of commercial development, though not as high as a commercial area and have residential development as well. There is a less distinct change in the day- and night- populations.

3) Mixed residential area does not have sufficient work for the population and some residents must commute to another area. These areas are distinguished by a higher nighttime population than day-time. However, these areas can have high population densities which support high store and service densities.

4) Autonomous areas have a roughly equal amount of residential and commercial development which allows residents to live and work within the area. There is not significant change in the day- and night-time populations. However, the population density is low and these areas are located quite far from major urban centers.

5) Unurbanized areas have low densities of both commercial and residential development and low employment opportunities.

The average characteristic values for each area are shown in Table 3.

\section{LIFECYCLE STAGES}

The strengths and weaknesses of the lifecycle concept in travel behavior have been discussed in many travel research papers, and these studies point to the presence of a lifecycle effect in travel behavior. Heggie (12) found evidence for the significance of family structure in an exploratory study of the reactions of Oxford residents to that city's policy of car restraint. He found that many of the reported responses were the results of behavior which was strongly constrained by family circumstances - these constraints being of a different nature depending on the numbers and ages of the children in the family. Jones et al. (13) used lifecycle stage as a key classificatory variable. Zimmerman (14) showed differences in the average daily trip 
frequency across households of different lifecycle stages; e.g., single parents and nuclear families show increases in trip-making as the household head becomes older. Clarke et al. (15) developed micro-analytic simulation models of travel behavior. They assess the implications for travel given various combinations of probabilities, through ageing a hypothetical population through various household types and lifecycle stages, and simulating the impact of demographic, socioeconomic, and location variables at each stage.

However, what these studies have argued about the application of the lifecycle concept in transportation planning is only beginning to be realized, and the concept has been used uncritically and simplistically. This paper considers not only the impact of lifecycle, but also the impact of the built environment for the fraction of all trips that are by private automobile and also the number of trips. Ten distinct stages of lifecycle were formulated as shown in Table 4.

\section{ANALYSIS}

Analysis of variance (ANOVA) was used to determine if the differences observed were statistically different for each separate analysis. ANOVA was completed for the fraction of automobile trips by all households across the previously defined developed areas for the years 1970, 1980, 1990, and 2000. It was then used to determine the differences between each lifecycle stage across each developed area for the year 2000. The final analysis was completed for the total number of household trips for each lifecycle stage across each developed area for the year 2000. All results were statistically valid at $p<0.001$ and the number of respondents was 146,820 for the year 2000 .

\section{RESULTS AND DISCUSSION}

Different built environments were identified for the Kei-Han-Shin area of Japan. Commercial and mixed commercial built environments were located at the "centers" of the three main cities of Kyoto, Osaka, and Kobe. Mixed residential was often just outside the centers of the main cities. The remaining areas were classified as autonomous or emerging depending on the constraints discussed in the Identifying Different Built Environments section.

\section{Increasing Fractions of Automobile Use}

In all areas except for the commercial and mixed-commercial areas, a significant growth in the fraction of household trips completed by automobile can be seen in Figure 1. From these results, it appears that the more densely developed built environments, commercial and mixed-commercial, had a limiting effect on the fraction of automobile trips. However, without knowing how households of different lifecycle stages behave within each of those areas, it could be argued that the same people are continuing to live in the commercial and mixed-commercial areas, and that their behavior is simply entrenched.

It is interesting to note that even in the most extreme cases, the fraction of household travel is roughly $50 \%$. Speculatively, this may be a result of mixed land-use in all areas.

\section{Lifecycle Stages within Different Built Environments}

In the last sub-section we saw that the rate of increase of the fraction of automobile trips was different for each built environment, but the types of households that live in each area may affect that result. This sub-section shows the results of comparing the different lifecycle stages described in the Identifying Different Built Environments section across each built environment for the year 2000 .

Figure 2 shows the fraction of automobile trips for each lifecycle stage within each built environment. The trend is that the fraction of automobile trips is related to the built environment, and less to the lifecycle stage. This result would suggest that the built 
environment and not the household type is a stronger explainer of the fraction of automobile trips.

A two variable ANOVA analysis (Table 5) of the built environment and lifecycle stage confirms that the built environment rather than lifecycle stages is a significant explainer for the fraction of automobile trips for a household. From that table, it can be seen that the portion explained by the built environment (Sum of Squares) is larger than either the lifecycle stage or the combined effect of the two.

However, there may still be variance between lifestyles within each lifecycle stage. Therefore, the number of trips that each household of the different lifecycle stages completes over a day will be compared. The number of trips may be an indication of how often the person engages in activities outside their home.

\section{Number of Trips by Households of the Same Lifecycle Stage across Different Built Environments}

The number of trips completed by a household is used here as a proxy for how often the household engages in activities outside the home. These results may show if there are significant differences in lifestyles (e.g. a high number of trips may suggest a highly active and engaged person, while a low number of trips may suggest a more sedentary life).

The results can be seen in Figure 3 which shows that there is very little difference across the built environments, but that differences can be seen across the lifecycle stages. This suggests that households of same lifecycle stage are completing a similar number of trips per day, no matter the built environment, and that there are distinct differences between lifecycle stages. This result in combination with the Figure 2 would suggest that the built environment will determine the fraction of automobile trips, and that the differences seen in Figure 1 are not a result of different household lifecycle or lifestyle with respect to the number of trips being made.

\section{Land Use and Travel Behavior in this Study}

This paper showed that there were underlying travel patterns for different built environments in the Kei-Han-Shin area of Japan with respect to the fraction of automotive trips per household (Figure 1). It showed that within the same lifecycle stages, that a similar difference could be seen amongst the different built environments (Figure 2). Lastly, it showed that the number of trips per household within the same lifecycle stage did not have extreme variances (Figure 3), implying similar levels of activity. The graphs are not household specific, but population-wide averages for the differentiated built environments, but Table 5 shows household-level results. All areas allowed for mixed land-use, though greater urbanization may facilitate greater diversity through increased population densities. This less strict zoning may contribute to the less than $50 \%$ fraction for lifecycle stages with children in all areas. It should be noted that children's travel in Japan is highly non-motorized (16) which could account for that result.

The different lifecycle stages clearly show different total numbers of trips, but it was the difference in the residential locations that showed different travel behavior with respect to automobile use. Further, research conducted in this same study area showed that structural changes were the most significant contributor to energy consumption over the period 1970 to 2000 (10). In contrast to the Giuliano and Hanson statement that household circumstances are a stronger influence than land use on travel patterns (5), these two results both suggest that the land use as an aspect of the built environment is perhaps more significant a determinant of how people will travel, while lifecycle stage predicts the number of trips that a household conducts. Although household income was not directly addressed in this paper, it should be noted that households of different income levels are highly mixed in the study area. What 
may be the case is that in an auto-oriented development area, the increase in trips required by an expanding family must be conducted by automobile. A wealthier family will have a greater ability to supply vehicles and to have the extra funds to participate in activities. On the other hand, in higher density, mixed land-use areas those extra trips can be completed by non-motorized modes or public transit. As noted above, children's travel during the week is highly non-motorized and independent of parents for more urban areas (16) which would support that assertion.

\section{Society Influences Our Behavior}

Human beings are social creatures and our instincts encourage us to follow general group behavior, called normative social influence. Although this tendency is stronger in certain cultures (17) it may help explain why in a study on the impact of different public transport service levels, no difference was observed in travel behavior in Los Angeles (9), which is dominated by private vehicle use. Conversely, as was mentioned in the introduction, roughly $60 \%$ of shopping trips are still done by non-motorized modes in the Kei-Han-Shin area of Japan, which likely contributes to the continued use of these modes over private vehicles despite an increase in ownership, as walking and cycling are the social norm. Unfortunately, as walking and cycling are not the social norm in North America, someone who is seen traveling by such modes will be subconsciously viewed with suspicion as evolution has taught us to see the non-group behavior as a threat (17).

To overcome these tendencies in humans, several things must change. Transit Demand Management (TDM) practices such as Voluntary Travel Behavior Change (VTBC) which work to overcome mental effort barriers can make changes to people's thinking and behavior (18), but to achieve greater change, the built environment must also change. This paper showed even when comparing households of the same lifecycle stage, that the built environment was a stronger explainer for the fraction of automotive trips. The potential for change is therefore likely greater with a built environment conducive to sustainable travel than conscientious individuals who are in a car-oriented built environment. Once the built environment has changed and more sustainable forms of travel are increasingly more possible, education such as VTBC may be more effective in changing overall behavior. Litman and Steele (3) give numerous examples of the more sustainable travel seen in mixed land-use development over mono-use areas. As well, medical research is now looking to the built environment as a way to improve physical health and results reflect those seen for environmentally improved development $(19,20,21)$.

Development patterns such as Smart Growth (22) propose how compact cities, TOD, and TDM can all combine to improve livability and sustainability of the urban built environment. As discussed above, the study area reflects many of the design principles proposed such as transit-based development, mixed land-use, and greater community cohesion $(10,16)$. This paper showed that areas with the highest population densities and commercial land use have had relatively low use of automobiles, even as increased motorization was seen in other less urban areas. In terms of energy use and health through non-motorized travel, those areas are more sustainable.

In democratic societies, it may be necessary to convince the voting public of the benefits of changing to development such as Smart Growth before they could occur. But with few examples of good, high-density, mixed land-use developments remaining in North America, it may be difficult for most people to imagine anything different than what currently exists. The hardest task may now be not proving the benefits of TOD-like development to researchers, but to the general public. Greater efforts are needed in the dissemination of such knowledge through media such as newspapers and television. 


\section{CONCLUSIONS}

This paper investigated how the built environment may create environments where more sustainable travel is possible by considering the fraction of automobile trips across different developed areas and within distinct lifecycle stages. The results suggest that the built environment has significant correlation with the fraction of automobile trips even when households of different lifecycle stages are compared. No significant differences were observed in the number of trips for households of the same lifecycle stage across different built environments, suggesting that similarly active lifestyles exist. These results suggest that significantly more sustainable behavior for society would be possible with more compact built environments that facilitate non-motorized and public transit travel. Unfortunately, it takes time, money, resources, and the political will to change the built environment and initial steps that educate the public such as voluntary travel behavior change may be necessary first steps on the move to more sustainable travel.

1. Matsuhashi, K. A study on the compact city in view of regional trip energy in Osaka metropolitan area. Journal of the City Planning Institute of Japan, Vol. 35, 2000, pp. 469-74, (in Japanese).

2. Nishihori, Y., A. Kondo, Y. Hirose, and T. Fujigawa. Location of commercial facilities related to desirable urban form. Advances in Transport, Vol. 8; urban transport VII: Urban transport \& the environment in the $21^{\text {st }} \mathrm{C}, 2001$, pp. 133-144

3. Litman, T. and R. Steele. Land Use Impacts on Transport: How Land Use Factors Affect Travel Behavior. Victoria Transport Policy Institute

4. Handy, S. Methodologies for Exploring the link b/w urban form and travel behavior.

Transportation Res., Vol.1, No.2, 1996, pp. 151-65,.

5. Giuliano, G. and S. Hanson. Managing the Auto. The Geography of Urban Transportation, $3^{\text {rd }}$ ed. Edited by S. Hanson and G. Giulinao, 2004, pp. 382-403

6. Waygood, E.O.D. and R. Kitamura. How Changing the Location of a Work Place Affects People's Travel. Paper presented at The $12^{\text {th }}$ International Conference of Hong Kong Society for Transportation Studies, Hong Kong, December, 2007.

7. Krizek, KJ. A pre-test/post-test strategy for researching neighbourhood-scale urban form and travel behaviour. J Transport Res Board No. 1722, 2000. pp. 48-55.

8. Cao, Xinyu, Patricia L. Mokhtarian, and Susan L. Handy. Examining The Impacts of Residential Self-Selection on Travel Behavior: Methodologies and Empirical Findings. Institute of Transportation Studies, University of California, Daivs, Research report UCDITS-RR-08-25, 2008.

9. Kitamura, R., T. Akiyama,T. Yamamoto, and T.F. Golob. Accessibility in a metropolis: Toward a better understanding of land use and travel.' Transportation Research Record, $\mathrm{n}$ 1780, 2001, p 64-75.

10. Kitamura, R., Sakamoto, O. Waygood. Declining Sustainability: The Case of Shopping Trip Energy Consumption. International Journal of Sustainable Transportation, Vol. 2, No. 3, 2008.

11. Sorenson, Andre. Making of Urban Japan. Routledge, London, 2002.

12. Heggie, I.G. Putting behaviour into behaviour models of travel choice. Journal of the Operational Research Society, Vol.29, No.6, 1978.

13. Jones, P.M., Dix, M.C., Clarke, M.I. and Heggie, I.G. Understanding travel behaviour.

Oxford, England: Transport Studies Unit, Oxford University, Ref. 119/PR, 1980.

14. Zimmerman, C.A. The lifecycle concept as a tool for travel research. Transportation, 11, 1982, pp.51-69. 
15. Clarke, M. I. Dix, M.C. and Goodwin, P. Some issues of dynamics in forecasting travel behavior - a discussed paper. Transportation, 11, 1982, pp. 153-172.

16. Waygood, E.O.D. and R. Kitamura. Children in a Rail-Based Developed Area of Japan: Travel Patterns, Independence, and Exercise. TRB Annual Meeting 2009 CD-ROM..

17. Baron, R.A., D. Byrne, and G. Watson. Exploring Social Pschology. Pearson Education Canada Inc., Toronto, 2005. pp. 254.

18. Werner, B. Global Problems Need Global Solutions - Behaviour Change in Three Continents. Paper presented at the $4^{\text {th }}$ International Symposium on Travel Demand Management, Vienna, Austria, July 16-18, 2008.

19. Boer, R., Y. Zheng, A. Overton, G.K. Ridgeway, and D.A. Cohen. Neighborhood Design and Walking Trips in Ten U.S. Metropolitan Areas. American Journal of Preventative Medicine, Vol. 32, No. 4, 2007, pp. 298-304.

20. Ewing, R., T. Schmid, R. Killingsworth, A. Zlot, and S. Raudenbush. Relationship Between Urban Sprawl and Physical Activity, Obesity, and Morbidity. The Science of Health Promotion, Vol. 18, No. 1, 2003.

21. Frank, L.D., M.A. Andresen, and T.L. Schmid. Obesity Relationships with Community Design, Physical Activity, and Time Spent in Cars. Vol. 27, No. 2, 2004, pp. 87-96. 22. Handy, S. Smart Growth and Transportation-Land Use Connection: What Does the Research Tell Us? International Regional Science Review. Vol. 28, No. 2, 2005, pp. 146-167. 
List of Tables

TABLE 1 Factors Used to Distinguish Different Developed Areas

TABLE 2 The Number of Distinct Developed Areas for the Years 1970, 1980, 1990, and 2000

TABLE 3 Characteristics of the five built environment areas.

TABLE 4 Descriptions and Definitions of Lifecycle Stages

TABLE 5 Results of ANOVA Analysis on the Fraction of Automobile Trips per Household for the Year 2000

List of Figures

FIGURE 1 Change in the fraction of automobile trips per household across different developed areas.

FIGURE 2 A comparison of the fraction of all trips that are by automobile for different household lifecycle stages across distinct developed areas for the year 2000.

FIGURE 3 The number of all trips for each household by lifecycle stage across different developed areas. 
TABLE 1 Factors Used to Distinguish Different Developed Areas

\begin{tabular}{|c|c|c|}
\hline Division & Factor & Source \\
\hline \multirow[t]{3}{*}{ (1)Population } & Population density (people $/ \mathrm{km}^{2}$ ) & National census \\
\hline & $\begin{array}{l}\text { Change in population between day and night } \\
(\%)\end{array}$ & $\begin{array}{l}\text { National census and } \\
\text { Municipal statistics }\end{array}$ \\
\hline & Population concentration (\%) & National census \\
\hline \multirow[t]{4}{*}{ (2)Commercial } & Office density (office $/ \mathrm{km}^{2}$ ) & $\begin{array}{l}\text { Report on offices } \\
\text { and enterprises }\end{array}$ \\
\hline & Retail shop density (shops $/ \mathrm{km}^{2}$ ) & $\begin{array}{l}\text { National manpower, } \\
\text { Census of } \\
\text { Commerce }\end{array}$ \\
\hline & Super market density (shops $/ \mathrm{km}^{2}$ ) & $\begin{array}{l}\text { National manpower, } \\
\text { Supermarket } \\
\text { directory }\end{array}$ \\
\hline & Service density (shops $/ \mathrm{km}^{2}$ ) & $\begin{array}{l}\text { Report on offices } \\
\text { and enterprises }\end{array}$ \\
\hline \multirow[t]{3}{*}{ (3)Employment } & Employment rate change (\%) & National census \\
\hline & Employment rate (\%) & National census \\
\hline & Commuter percentage (\%) & $\begin{array}{l}\text { National census and } \\
\text { Municipal statistics }\end{array}$ \\
\hline \multirow[t]{2}{*}{ (4)Household } & Single person household percentage & $\begin{array}{l}\text { National census and } \\
\text { Municipal statistics }\end{array}$ \\
\hline & Average household size (people/household) & $\begin{array}{l}\text { National census and } \\
\text { Municipal statistics }\end{array}$ \\
\hline \multirow[t]{3}{*}{ (5)Individuals } & Average age (years) & National census \\
\hline & Elderly percentage & $\begin{array}{l}\text { National census and } \\
\text { National manpower }\end{array}$ \\
\hline & Youth percentage & $\begin{array}{l}\text { National census and } \\
\text { Municipal manpower }\end{array}$ \\
\hline $\begin{array}{l}\text { (6) Private } \\
\text { automobile } \\
\text { ownership }\end{array}$ & $\begin{array}{l}\text { Average household ownership } \\
\text { (vehicles/household) }\end{array}$ & $\begin{array}{l}\text { Municipal Household } \\
\text { Vehicle Ownership } \\
\text { Registration }\end{array}$ \\
\hline
\end{tabular}


TABLE 2 The Number of Distinct Developed Areas for the Years 1970, 1980, 1990, and 2000

\begin{tabular}{|l|c|c|c|c|}
\hline & $\mathbf{1 9 7 0}$ & $\mathbf{1 9 8 0}$ & $\mathbf{1 9 9 0}$ & $\mathbf{2 0 0 0}$ \\
\hline Commercial & 5 & 7 & 8 & 7 \\
\hline Mixed commercial-residential & 23 & 26 & 27 & 31 \\
\hline Mixed residential & & & & 110 \\
\hline Autonomous & 45 & 103 & 110 & 31 \\
\hline Unurbanized area & 98 & 26 & 27 & 12 \\
\hline
\end{tabular}


TABLE 3 Characteristics of the five built environment areas.

\begin{tabular}{|c|c|c|c|c|c|}
\hline & $\begin{array}{c}\text { Highly } \\
\text { Commercial }\end{array}$ & $\begin{array}{c}\text { Mixed } \\
\text { Commercial }\end{array}$ & $\begin{array}{c}\text { Mixed } \\
\text { Residential }\end{array}$ & Autonomous & Undeveloped \\
\hline \multirow{3}{*}{$\begin{array}{l}\text { Household } \\
\text { size }\end{array}$} & 1 to 10 & 1 to 13 & 1 to 13 & 1 to 10 & 1 to 9 \\
\hline & 2.2 & 2.5 & 2.9 & 3.1 & 3.3 \\
\hline & 2 & 2 & 3 & 3 & 3 \\
\hline \multirow[t]{3}{*}{ HH cars } & 0 to 12 & 0 to 11 & 0 to 15 & 0 to 12 & 0 to 15 \\
\hline & 0.49 & 0.623 & 1.11 & 1.63 & 1.82 \\
\hline & 0 & 0 & 1 & 1 & 2 \\
\hline \multirow{3}{*}{$\begin{array}{c}\mathrm{HH} \\
\text { motorcycles }\end{array}$} & 0 to 10 & 0 to 8 & 0 to 11 & 0 to 7 & 0 to 6 \\
\hline & 0.15 & 0.17 & 0.3 & 0.45 & 0.5 \\
\hline & 0 & 0 & 0 & 0 & 0 \\
\hline \multirow[t]{3}{*}{ HH bicycles } & 0 to 7 & 0 to 9 & 0 to 9 & 0 to 9 & 0 to 9 \\
\hline & 1.13 & 1.44 & 1.34 & 1.36 & 0.92 \\
\hline & 1 & 1 & 1 & 1 & 0 \\
\hline \multirow{3}{*}{$\begin{array}{c}\text { Population } \\
\text { Density } \\
\text { (people/km2) }\end{array}$} & 4224 to 12594 & 5493 to 18757 & 48 to 16114 & 74 to 2457 & 35 to 1976 \\
\hline & 8985 (36/acre) & 12620 (51/acre) & 3770 (15/acre) & 1138 (4.6/acre) & 493 (2.0/acre) \\
\hline & 7717 (31/acre) & 11934 (48/acre) & 3191(13/acre) & 843 (3.4/acre) & 373 (1.5/acre) \\
\hline \multirow{3}{*}{$\begin{array}{c}\text { Service } \\
\text { Density } \\
\text { (businesses/ } \\
\text { km2) }\end{array}$} & 222 to 1137 & 97 to 776 & 0 to 208 & 0.6 to 25 & 0.5 to 15 \\
\hline & 558 (2.3/acre) & 189 (0.76/acre) & 38.1 (0.15/acre) & 15 (0.06/acre) & 4 (0.02/acre) \\
\hline & 339 (1.4/acre) & 163 (0.66/acre) & 31.2 (0.13/acre) & 12 (0.05/acre) & 2 (0.01/acre) \\
\hline
\end{tabular}


TABLE 4 Descriptions and Definitions of Lifecycle Stages

\begin{tabular}{|c|c|c|c|}
\hline & Acronym & Descriptions & Definitions \\
\hline $\mathbf{A}$ & Younger single & Younger single household & Single adult with age under 60 \\
\hline B & Younger childless couple & \multirow{2}{*}{$\begin{array}{l}\text { Younger childless-couple household } \\
\text { Nuclear families with pre-school } \\
\text { children }\end{array}$} & Oldest person under 60 \\
\hline C & Pre-school nuclear & & Youngest child under 6 \\
\hline D & Young school nuclear & $\begin{array}{l}\text { Nuclear families with young school } \\
\text { children }\end{array}$ & $\begin{array}{l}\text { Youngest child } 6 \text { or over but } \\
\text { under } 12\end{array}$ \\
\hline$E$ & Older school nuclear & $\begin{array}{l}\text { Nuclear families with older school } \\
\text { children }\end{array}$ & $\begin{array}{l}\text { Youngest child } 12 \text { or over but } \\
\text { under } 18 \\
\text { Nuclear families and single }\end{array}$ \\
\hline $\mathbf{F}$ & All adults & Families of all adults & $\begin{array}{l}\text { parent families with all } \\
\text { members of working age }\end{array}$ \\
\hline G & Older childless couple & Older childless-couple household & Oldest person 60 or over \\
\hline H & Older single & Older single household & Age 60 or over \\
\hline I & Single parent & Single-parent household & Youngest child under 18 \\
\hline $\mathbf{J}$ & Others & Other households & $\begin{array}{l}\text { Families with three generation, } \\
\text { other related persons and } \\
\text { unrelated persons }\end{array}$ \\
\hline
\end{tabular}




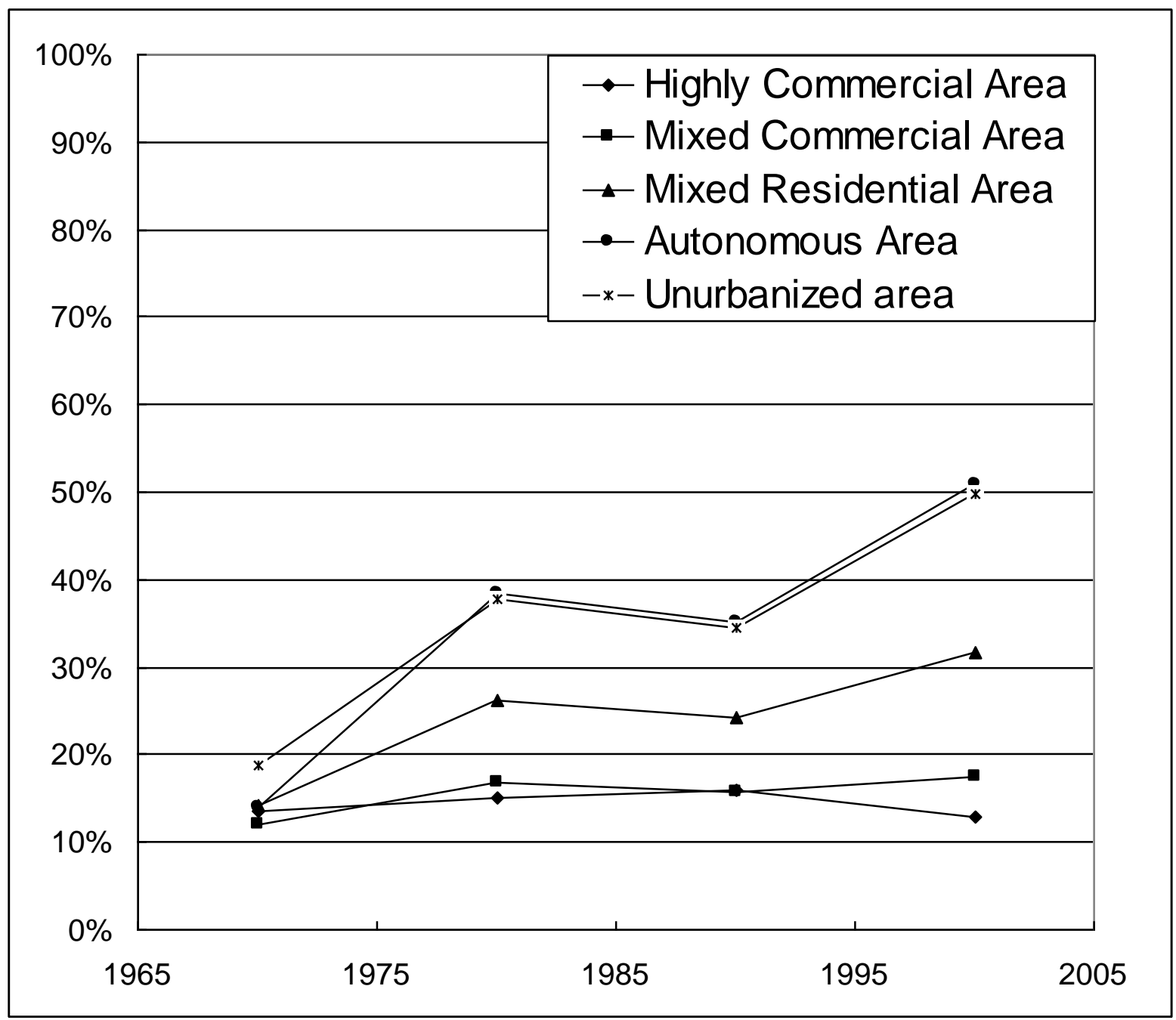

FIGURE 1 Change in the fraction of automobile trips per household across different developed areas. 


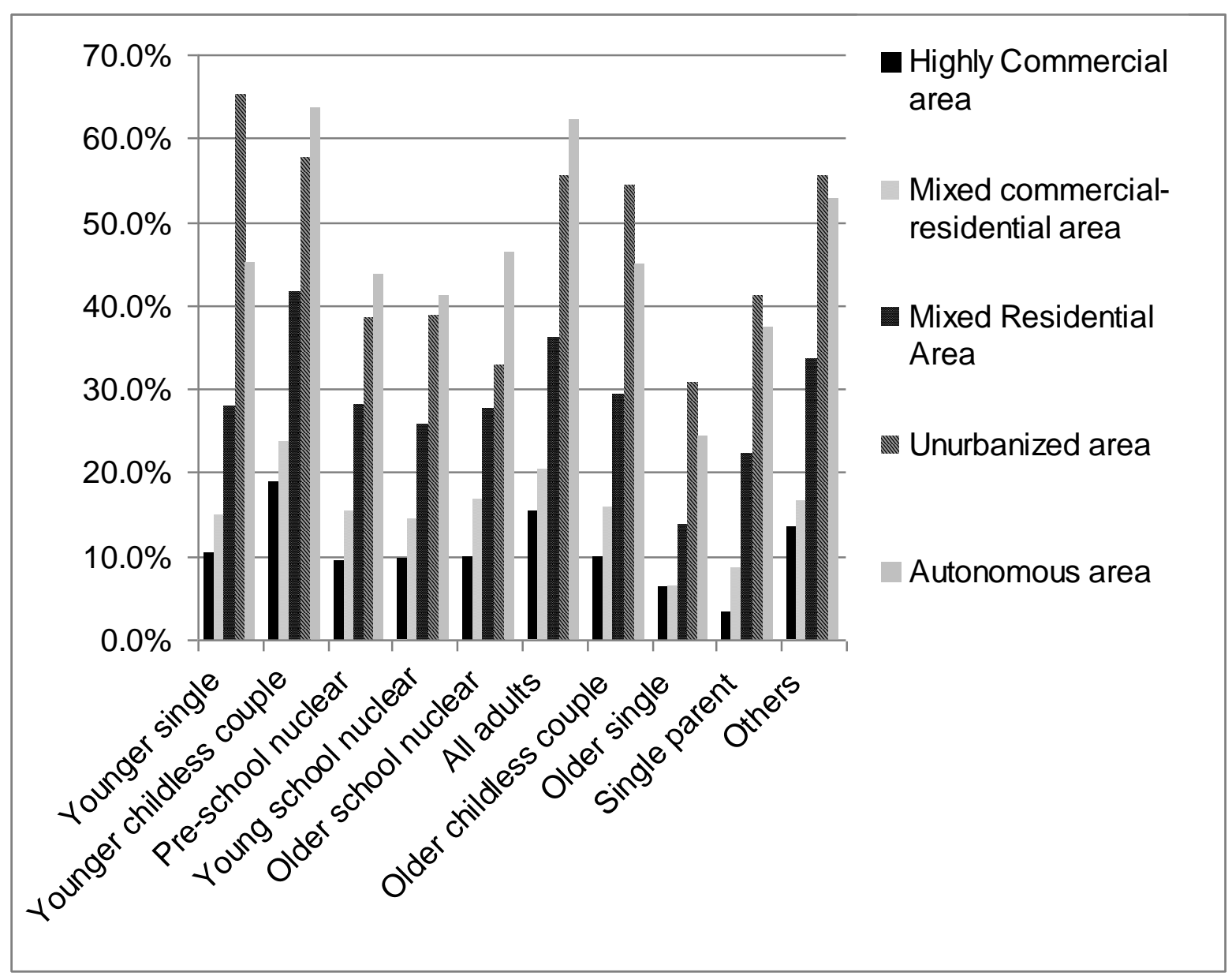

FIGURE 2 A comparison of the fraction of all trips that are by automobile for different household lifecycle stages across distinct developed areas for the year 2000 . 
TABLE 5 Results of ANOVA Analysis on the Fraction of Automobile Trips per Household for the Year 2000

\begin{tabular}{|l|c|c|c|c|}
\hline & Sum of Squares & $\begin{array}{c}\text { Degrees of } \\
\text { Freedom }\end{array}$ & Mean Square & F \\
\hline Corrected Model & 1510.8 & 49 & 30.8 & $290.6^{*}$ \\
\hline Intercept & 794.6 & 1 & 794.6 & $7490.2^{*}$ \\
\hline Built Environment (BE) & 577.5 & 4 & 144.4 & $1360.8^{*}$ \\
\hline Lifecycle stage (LCS) & 58.0 & 9 & 6.4 & $60.7^{*}$ \\
\hline LCS x BE & 45.9 & 36 & 1.3 & $12.0^{*}$ \\
\hline Error & 11685.5 & 110146 & 0.11 & \\
\hline Total & 21551.7 & 110196 & & \\
\hline Corrected Total & 13196.3 & 110195 & & \\
\hline
\end{tabular}

$*=$ significant at $\alpha=0.05$

$N=146,820$ 


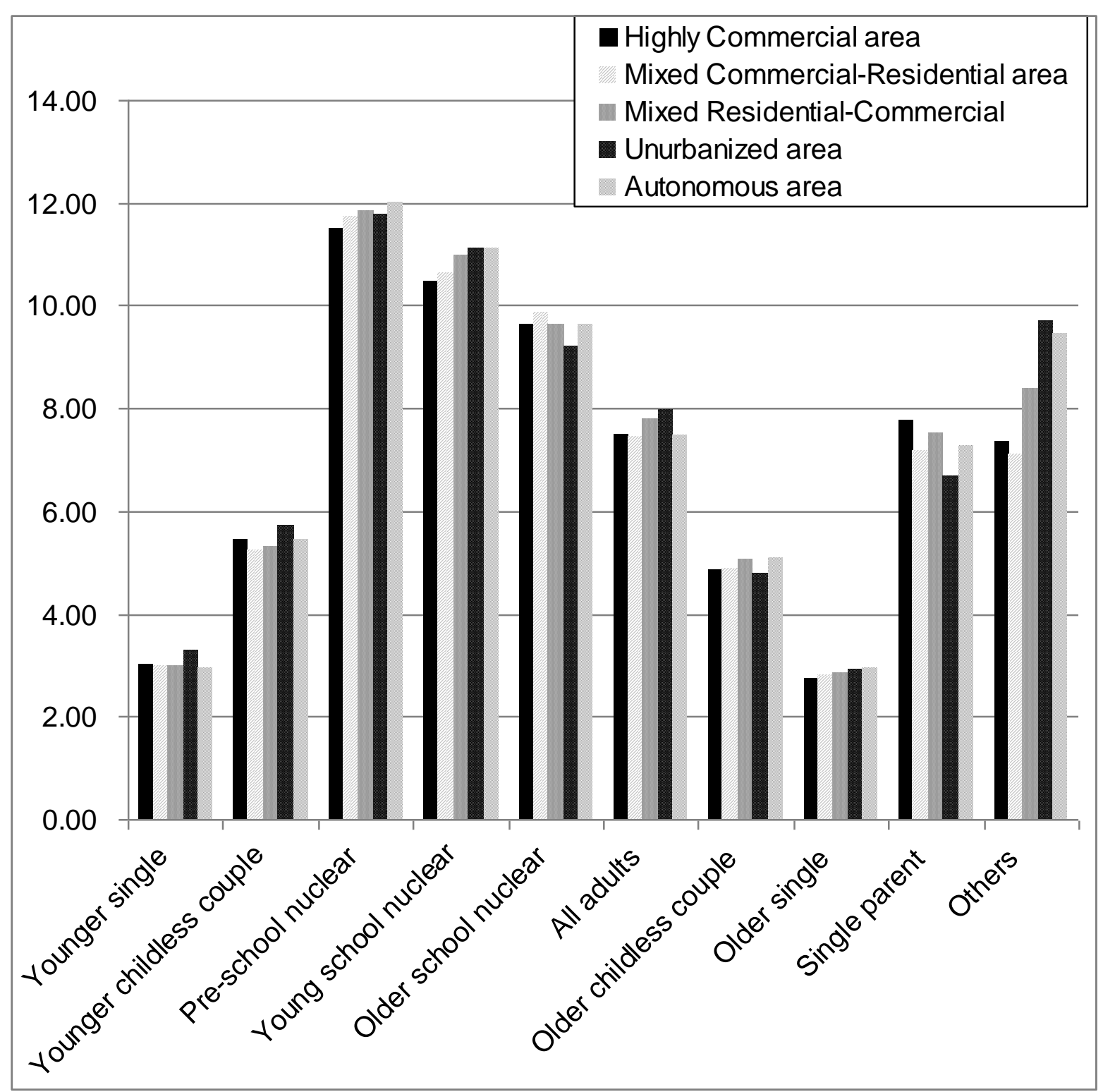

FIGURE 3 The number of all trips for each household by lifecycle stage across different developed areas. 